\title{
Creating Welcoming Schools: A Practical Guide to Home-School Partnerships with Diverse Families
}

\author{
Chris Sclafani ${ }^{1}$ \\ ${ }^{1}$ Department of Literacy Studies, Hofstra University, Hempstead, NY, USA \\ Correspondence: Chris Sclafani, Department of Literacy Studies, Hofstra University, Hempstead, NY, USA.
}

Received: January 28, 2018

Accepted: March 22, 2018

Online Published: April 20, 2018

doi:10.20849/jed.v2i1.369

URL: https://doi.org/10.20849/jed.v2i1.369

\begin{abstract}
The connection between the school life of students and their home lives is extremely important in today's world. Learning must be extended beyond the walls and doors of the physical school environment. In order to impress this point upon children, parents must be fully involved in the educational process. When families feel a sense of detachment towards the stakeholders in their child's learning, a sense of apathy towards school-related items can begin to occur. This must avoided at all costs. JoBeth Allen delves into the various ways that schools, communities, and parents can come together to form an optimal pedagogical environment. Allen places well-developed narratives throughout her book to allow the reader to reflect and understand the complexities that exist within the challenges of forming these vital home-school-community bonds. The ideas contained in Creating Welcoming Schools: A Practical Guide to Home-School Partnerships With Diverse Families are useful for a vast range of age and grade levels, and the recommended strategies can be gradually employed according the comfort and experience level of the individual educator who is implementing them.
\end{abstract}

Keywords: teaching, education, home-school connection, welcoming classrooms, learning

\section{Introduction}

Creating Welcoming Schools: A Practical Guide to Home-School Partnerships With Diverse Families by JoBeth Allen is a powerful text that examines the often complex and diverse relationships between teachers, parents, and the community. Though it has been in publication for just under a decade, it maintains its importance and relevance in impressive fashion. "At the risk of stating the obvious, one of the most important things we learn from sustained, respectful dialogue between educators and families is how unique each family is" (Allen, 2008, p. 57). Allen uses an effective blend of personal narratives, classroom vignettes, and pertinent educational theory to demonstrate the various themes being presented. At a time when those in the political forum refer to "failing schools" and the need for "teacher accountability", this book could be of great value to those in a teaching profession that must now work even harder to maintain trust from those who are outside of the immediate school environment.

\section{Critical Review}

The reader is quickly made aware that building a home-school relationship requires cooperation at all levels, from the security guard at the door to the highest ranking administrator. The introduction and the opening chapter make this point rather obvious, as Allen (2008) employs a vivid hypothetical scenario about a bilingual father who visits the school for the first time to enroll his children. He is not treated with respect by the secretary and the experience leaves him with a feeling of general distrust for the school before his children have ever even attended (p. 1). This point is reiterated by renowned theorist Frank Smith (2007) when referring to the results of such interactions, "But everyone knows that first impressions make a difference" (p. 31). Allen notes that schools need to have operating procedures in place and a consistently welcoming message in order to prevent wholly avoidable, negative misconceptions.

The tone of this book then shifts rapidly towards practical advice and lesson ideas for teachers. The inclusion of parents is viewed as a key element in a vast majority of this advisement. "Parents bear the most immediate and direct responsibility for nurturing and caring for their children" (Garcia \& Frede, 2010, p. 16). Cultural capital becomes a major commodity. "The concept of funds of knowledge has influenced my thinking about connecting schools and homes more than perhaps any educational effort" (Allen, 2008, p. 42). Under the "funds of 
knowledge" thought process, the family is viewed as a priceless resource that must be tapped to ensure optimal results for the child. The central strength of this section is the simplicity of the projects. The work ranges from the traditional collaborative family tree work to innovative parent and child short poems that establish parental values and interests. Additionally, much is done with photography from the home. This photography is inherently linked to school as students and parents will come together to search for, and review the pictures, which will then be used to make maps or narrative stories. The selected pictures, and the work that accompanies them will then be shared with class as part of a further community of learners. Allen (2008) said of these projects, "We learned new ways for ourselves as teachers to connect with and reenvision children and family members" (p. 54). This repositioning of children as members of both family and class will naturally foster greater interaction between the teacher and home.

The author's devotion to an egalitarian approach to dialogue is certainly a major takeaway for the reader. Respect for parents, children, and other professionals is placed at the forefront of all communicative experiences. Author Carole Edelsky (2006) concurs that this is a nuanced process that must be refined, as she writes, "Values of respect and caring (for and about) entail particular interpersonal dynamics" (p. 36). High value is placed on the parent-teacher conference discussion, as this is often the main point in the school year where parents meet privately with the exclusive goal of discussing their child. Allen shares an unorthodox, yet provocative vignette about a teacher who invited the students to these conferences as equal partners. While many instructors might bristle at this notion, apparently this strategy was effective in its context. "Sandy prepared the children to present their own work, to go over accomplishments, and to explain areas where they needed further work. These were the best conferences I ever attended" (Allen, 2008, p. 86). There is also a nod to genuine data-driven evidence to generate productive dialogue about potentially negative aspects of student performance, instead of reverting into an unequal authoritarian role which could be destructive. "Concrete evidence enables dialogue" (Allen, 2008, p. 87). If one is speaking from documentation, it promotes a far less argumentative stance from parents.

As important as enabling dialogue might be, sustaining that dialogue is something that must be placed as a high priority as well. Allen promotes events like "Family Literacy Night" and "Parents as Classroom Storybook Readers" as a means of getting parents into schools to become directly involved in the learning experiences of the students. "When parents saw how interactive the children at school were during the storybook reading, they began to encourage more interaction during home reading" (Allen, 2008, p. 97). Beyond the valuable parent-child interactions that occur at these happenings, the teacher once again is able to be reinforced strategies with the families about creating links from home to school.

The final chapters of the book deal with connecting the community with the parent-child relationship. Allen posits that this type of partnership works best when faculty members truly understand the school's surrounding community. "It just won't work to guess at local cultures" (Allen, 2008, p. 155). She recommends hiring a community liaison or opening a family room in the school where teachers can become more informed about the town that their students are being raised in. Parents and faculty can then guide the students to understand how their education expands far beyond the walls of home and school, and how they can have a positive impact on the world. "In other words, teachers have a responsibility to teach in ways that promote a fair and equitable society" (Allen, 2008, p. 127). It is not overlooked that these students must be active citizens in a democratic society.

\section{Conclusion}

This is a book that can serve to change the way school is viewed by parents and other public figures. As touched upon earlier, complex teacher evaluation systems often give those outside of the profession the wrongful impression that educators must be monitored in order to remain motivated workers. The transparency created by the practices that Allen promotes might assist in elevating the teaching profession above a status that educational author, Patrick Shannon (2007) refers to as "teachers as targets" (p. 166). Though the book is under two hundred pages, the content is rich with ideas and processes to include and impress parents, along with the general public, with the work and interaction of students. It's straightforward and jargon-free language provides the reader with a solid belief that these are realistic recommendations that bear potentially positive results. Perhaps, if parents and other members of society team up with schools, that newfound solidarity will allow teachers to remove the so-called targets from their collective backs, and they provide more readily for the greater good of children, parents, as well as local and global society.

\section{References}

Allen, J. (2008). Creating welcoming schools: A practical guide to home-school partnerships with diverse families. New York, NY: Teachers College Press. 
Edelsky, C. (2012). With literacy and justice for all: Rethinking the social in language education. New York, NY: Routledge.

García E. \& Frede E. (2010). Young english language learners current research and emerging directions for practice and policy. New York, NY: Teachers College Press.

Shannon, P. (2007). Reading against democracy: The broken promises of reading instruction. Portsmouth, NH: Heinemann.

Smith, F. (2007). Reading FAQ. New York, NY: Teachers College Press.

\section{Copyrights}

Copyright for this article is retained by the author(s), with first publication rights granted to the journal.

This is an open-access article distributed under the terms and conditions of the Creative Commons Attribution license (http://creativecommons.org/licenses/by/4.0/). 